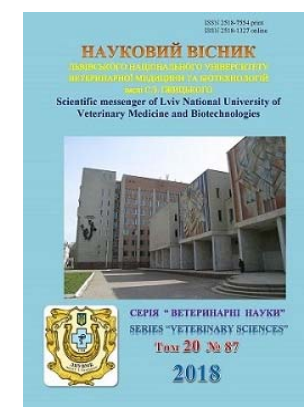

\author{
Науковий вісник Дьвівського національного університету \\ ветеринарної медицини та біотехнологій імені С.З. Гжицького
}

\author{
Scientific Messenger of Lviv National University \\ of Veterinary Medicine and Biotechnologies
}

\title{
Therapeutic effectiveness of probiotic and phytobiotic for gastroenteritis of weaned piglets
}

\author{
L.G. Slivinska, B.O. Lukashchuk
}

Stepan Gzhytskyi National University of Veterinary Medicine and Biotechnologies Lviv, Ukraine

Article info

Received 15.02.2018

Received in revised form 23.03.2018

Accepted 26.03.2018

Stepan Gzhytskyi National University of Veterinary Medicine and Biotechnologies Lviv, Pekarska str., 50, Lviv, 79010, Ukraine. Tel.:+38-097-976-70-75 E-mail:lukaw4yk@gmail.com
Slivinska, L.G., \& Lukashchuk, B.O. (2018). Therapeutic effectiveness of probiotic and phytobiotic for gastroenteritis of weaned piglets. Scientific Messenger of Lviv National University of Veterinary Medicine and Biotechnologies. 20(87), 85-88. doi: 10.15421/nvlvet8717

The inappropriate use of chemically synthesized antibacterial drugs, including fodder antibiotics, leads to a disturbance of the microbial ecosystems of the digestive canal and the appearance of pathogenic and opportunistic microorganisms of resistance to them. Therefore, in recent years, the use of animal-safe and environmentally friendly probiotics and phytobiotics has become widespread. Their action is aimed at the normalization of metabolic processes in the body and the mobilization of protective factors of the immune system, which is an effective alternative to traditional methods of prevention and treatment of diseases of the gastrointestinal tract. The article presents data on the influence of probiotic TOYOCERIN10 and phytobiotic EXTRACT TM 6930 in combination with antibiotic (10\% solution of enrofloxacin hydrochloride) on the clinical and haematological status of excised piglets, patients with gastroenteritis and their safety. The positive influence of probiotic and phytobiotic on the state of erythrocytopoesis was established. In particular, after treatment in experimental piglets, the number of erythrocytes decreased by $14.3 \%(P<0.001)$ and $13.4 \%(P<0.001)$, the hemoglobin content was $10.5 \%(P<0.01)$ and $13.1 \%(P<0.001)$ compared to the animals before treatment and reached the level of clinically healthy animals. The value of hematocrit in the blood of the exterminated piglets of all groups after treatment has reached the level of indices of clinically healthy animals. It is important to note that the use of probiotic and phytobiotic has positively influenced the leukocytopoiesis of piglets, as indicated by a decrease in the number of leukocytes in the blood of piglets in experimental groups by 26.9\% $(P<0.001)$ and $25.4 \%(P<0.001)$, compared with animal characteristics before treatment. Treatment of piglets using $10 \%$ solution of enrofloxacin hydrochloride, contributed to the improvement of the clinical condition of diseased animals in the 7-9th day, whereas in piglets, which were additionally used probiotic TOYOCERIN $10^{9}$ on 5-7th in the phytobiotic EXTRACT ${ }^{\mathrm{TM}} 6930$ - on the 3-5th day. It was established that the use of probiotic TOYOCERIN $10^{9}$ and the phytobiotic EXTRACT ${ }^{\mathrm{TM}} 6930$ in combination with the antibiotic increased the safety of experimental group piglets by $12.8 \%$ and $17.0 \%$, as compared to the control group.

Key words: weaned piglets, antibiotic, probiotic, phytobiotic, gastroenteritis, erythrocytes, hemoglobin, hematocrit, leukocytes, preservation.

\section{Терапевтична ефективність пробіотика та фітобіотика за гастроентериту відлучених поросят}

\author{
Л.Г. Слівінська, Б.О. Лукащук
}

Львівський національний університет ветеринарної медицини та біотехнологій імені С.3. Гжицького, м. Львів, Україна

\footnotetext{
Нерачіональне використання хімічно синтезованих антибактеріальних препаратів, в тому числі кормових антибіотиків призводить до порушення мікробних екосистем травного каналу та появи у патогенних і умовно-патогенних мікроорганізмів стійкості до них. Тому в останні роки широке розповсюдження отримало використання безпечних для організму тварин та екологічно чистих пробіотиків та фітобіотиків. Їх дія спрямована на нормалізацію метаболічних процесів в організмі та мобілізацію захисних факторів імунної системи, шчо ефективною альтернативою традиційним методам профілактики і лікування хвороб шлунковокишкового каналу. У статті наведено дані шеоо впливу пробіотика ТОЙОЦЕРІН $10^{9}$ та фітобіотика ЕКСТРАКТтм 6930 у поєд-
} 
нанні з антибіотиком (10\% розчин енрофлоксачину гідрохлориду) на клініко-гематологічний статус відлучених поросят, хворих на гастроентерит і їх збереженість. Встановлено позитивний вплив пробіотика та фітобіотика на стан еритроиитопоезу. Зокрема, після лікування в крові поросят досліднх груп кількість еритроцитів зменшилась на 14,3\% (P < 0,001) $i$ 13,4\% (P < 0,001), вміст гемоглобіну - на 10,5\% (P<0,01) i 13,1\% (P<0,001) порівняно з показниками тварин до лікування та досягла рівня клінічно здорових тварин. Величина гематокриту в крові відлучених поросят всіх груп після лікування досягла рівня показників клінічно здорових тварин. Важливо зазначити, щуо застосування пробіотика та фітобіотика позитивно вплинуло на лейкоцитопоез поросят, на щзо вказує зменшення кількості лейкоцитів в крові поросят дослідних груп на 26,9\% (P<0,001) i 25,4\% (P<0,001), порівняно з показниками тварин до лікування. Лікування поросят із застосуванням 10\% розчину енрофлоксацину гідрохлориду, сприяло поліпшенню клінічного стану хворих тварин на 7-9-ту добу, тоді як у поросят, яким додатково застосовували пробіотик ТОЙОЦЕРІН $10^{9}$ - на 5-7-му та фітобіотик ЕКСТРАКТТм 6930 - на 3-5-ту добу. Встановлено, що застосування пробіотика ТОЙОЦЕPIH $10^{9}$ та фітобіотика ЕКСТРАКТТм 6930 у поєднанні з антибіотиком підвищило збереженість поросят дослідних груп на 12,8 i 17,0\%, порівняно до контрольної групи.

Ключові слова: відлучені поросята, гастроентерит, антибіотик, пробіотик, фітобіотик, еритроцити, гемоглобін, гематокрит, лейкоцити, збереженість.

\section{Ветуп}

Профілактичні та лікувальні заходи на сучасних свинокомплексах передбачають застосування хімічно синтезованих антибактеріальних препаратів, в тому числі кормових антибіотиків. Проте, їх нераціональне використання призводить до порушення мікробних екосистем травного каналу та появи у патогенних i умовно-патогенних мікроорганізмів стійкості до них (Cromwell, 2002; Chowdhury et al., 2009; Holman and Chénierab, 2015).

Ефективною альтернативою традиційним методам профілактики i лікування хвороб шлунковокишкового каналу $є$ застосування препаратів 3 вмістом природних біологічно активних речовин, дія яких спрямована на нормалізацію метаболічних процесів в організмі та мобілізацію захисних факторів імунної системи.

В останні роки широке розповсюдження отримало використання безпечних для організму тварин та екологічно чистих пробіотиків і фітобіотиків.

Пробіотики - біологічні препарати, до складу яких входять симбіонтні мікроорганізми (лактобактерії, біфідобактерії, грам-позитивні коки, дріжджі) або продукти їхнього метаболізму. Вони продукують бактеріоцини, які мають антимікробну дію проти патогенних штамів кишкової мікрофлори та молочну кислоту, визначаючи стан кислотності у шлунковокишковому каналі (Silva et al., 2010; Živković et al., 2011; Kiczorowska et al., 2017).

Фітобіотики - це препарати, що містять екстракти рослин, ефірні масла, природні алкоголі та алкалоїди, отримані 3 трав або спецій, які мають ароматичні й функціональні властивості. Ці препарати зазвичай не представляють жодної харчової цінності для свиней, але володіють цілим діапазоном властивостей. Фітобіотики здатні стимулювати апетит, забезпечувати антиоксидантний захист, модифікувати рН кишечнику, покращувати перетравлюваність кормів і ефективність конверсії корму. Деякі з них діють як ароматизатори, фунгістатики. Природні рослинні сполуки спричиняють повільний біологічний ефект, який не супроводжується різкими змінами гомеостазу та побічними ефектами, характерними для більшості фармакологічних препаратів (Kommera et al., 2006; Jacela et al., 2010).

Метою досліджень було визначити вплив пробіотика ТОЙОЦЕРІН $10^{9}$ та фітобіотика ЕКСТРАКТ
6930 у поєднанні з антибіотиком (10\% розчин енрофлоксацину гідрохлориду) на клініко-гематологічний статус відлучених поросят, хворих на гастроентерит i їх збереженість.

\section{Матеріал і методи досліджень}

Дослідження проводилися в ПАП «Агропродсервіс» Тернопільського району Тернопільської області та на кафедрі внутрішніх хвороб тварин та клінічної діагностики Львівського національного університету ветеринарної медицини імені С.3. Гжицького. Для досягенення поставленої мети було сформовано три групи відлучених поросят (контрольна та дві дослідні) $(\mathrm{n}=10)$ породи Ландрас з явними клінічними ознаками гастроентериту 30 -добового віку.

Поросят контрольної та дослідних груп лікували розчином енрофлоксацину гідрохлориду (в/м у дозі 0,5 мл/10 кг маси тіла тварини один раз на добу протягом 5 діб). Поросятам першої дослідної групи додатково застосовували пробіотик ТОЙОЦЕРІН $10^{9}$ (Ломанн Анімал Нутрішн, Німеччина) у дозі 0,5 г/кг комбікорму, другої - фітобіотик ЕКСТРАКТ ${ }^{\mathrm{M}} 6930$ (Панкосма С.А., Швейцарія) 0,15 г/кг комбікорму до 45добового віку.

Матеріалом для дослідження була кров, отримана 3 краніальної порожнистої вени до початку лікування (30-добовий вік) та після його проведення (37-добовий вік).

Визначення кількості лейкоцитів, еритроцитів, вмісту гемоглобіну та гематокритної величини проводили в стабілізованій ЕДТА крові за допомогою автоматичного гематологічного аналізатора Mythic 18 (Швейцарія) 3 використанням реагентів фірми $\mathrm{PZ}$ Cormay S.A. (Польща). Контроль клінічного статусу поросят проводили щодобово впродовж дослідного періоду за загальноприйнятими методиками (Vlizlo et al., 2012).

Статистичну обробку результатів досліджень проводили за допомогою стандартного пакету «Statistica», у програмі Microsoft Excel 2013, оцінюючи вірогідність показників ( $<<0,05$; $\mathrm{P}<0,01 ; \mathrm{P}<0,001)$ за критерієм Стьюдента.

При виконанні експериментальних досліджень на поросятах дотримано всіх біоетичних норм по відношенню до тварин, що відповідають вимогам Закону України «Про захист тварин від жорстокого поводження» від 28.03.2006 р. та «Свропейській конвенції 
на захист хребетних тварин» від 13.11.1987 р. Наказу Міністра освіти і науки, молоді та спорту України 01.03.2012 р. № 249. Зареєстровано в Міністерстві юстиції України 16 березня 2012 р. за № 416/20729 про «Порядок проведення науковими установами дослідів, експериментів на тваринах» (Official Journal of the European Union, 2010).

\section{Результати та їх обговорення}

Після лікування в крові поросят контрольної та дослідних груп кількість еритроцитів зменшилась на 8,7\% (P<0,05), 14,3\% ( $<<0,001)$ i 13,4\% ( $<<0,001)$, порівняно 3 показниками тварин до лікування (табл. 1). Проте в поросят дослідних груп цей показ- ник досягнув рівня показників клінічно здорових тварин.

Вміст гемоглобіну в крові поросят першої та другої дослідних груп після проведеного лікування зменшився на $10,5 \%$ ( $<0,01)$ і 13,1\% (Р < 0,001) відповідно, порівняно 3 показниками до лікування. Цей показник теж нормалізувався та досягнув рівня клінічно здорових тварин (табл. 1).

Величина гематокриту в крові відлучених поросят всіх груп після лікування досягла рівня показників клінічно здорових тварин.

Після лікування в крові поросят контрольної та дослідних груп кількість лейкоцитів зменшилась на $16,3 \%(\mathrm{P}<0,01), 26,9 \%(\mathrm{P}<0,001)$ i $25,4 \%(\mathrm{P}<0,001)$, порівняно 3 показниками тварин до лікування (табл. 2).

\section{Таблиця 1}

Показники еритроцитопоезу відлучених поросят до і після лікування гастроентериту $(\mathrm{n}=10)$

\begin{tabular}{|c|c|c|c|c|c|}
\hline \multirow[b]{2}{*}{ Група } & \multirow{2}{*}{$\begin{array}{c}\text { Період } \\
\text { дослідження }\end{array}$} & \multirow{2}{*}{$\begin{array}{c}\text { Біометричний } \\
\text { показник }\end{array}$} & \multicolumn{3}{|c|}{ Показник } \\
\hline & & & Еритроцити, Т/л & Гемоглобін, г/л & $\begin{array}{c}\text { Гематокритна } \\
\text { величина, \% }\end{array}$ \\
\hline \multirow{2}{*}{\multicolumn{2}{|c|}{ Клінічно здорові }} & Lim & $4,9-6,3$ & $79,4-108,1$ & $32,6-45,2$ \\
\hline & & $\mathrm{M} \pm \mathrm{m}$ & $5,7 \pm 0,13$ & $96,4 \pm 2,91$ & $38,5 \pm 1,26$ \\
\hline \multirow{4}{*}{ Контрольна } & \multirow{2}{*}{ До лікування } & Lim & $6,1-7,7$ & $94,9-114,1$ & $37,3-48,1$ \\
\hline & & $\mathrm{M} \pm \mathrm{m}$ & $6,9 \pm 0,17^{000}$ & $106,9 \pm 2,02^{\circ}$ & $43,0 \pm 1,19^{\circ}$ \\
\hline & \multirow{2}{*}{ Після лікування } & Lim & $5,5-6,9$ & $96,8-111,6$ & $33,4-46,1$ \\
\hline & & $\mathrm{M} \pm \mathrm{m}$ & $6,3 \pm 0,13^{\prime 00}$ & $103,2 \pm 1,74^{\circ}$ & $40,1 \pm 1,35$ \\
\hline \multirow{4}{*}{ Дослідна 1} & \multirow{2}{*}{ До лікування } & Lim & $6,2-7,8$ & $95,6-118,4$ & $35,9-47,9$ \\
\hline & & $\mathrm{M} \pm \mathrm{m}$ & $7,0 \pm 0,18^{\circ 00}$ & $107,1 \pm 2,39^{\circ}$ & $42,7 \pm 1,11^{\circ}$ \\
\hline & \multirow{2}{*}{ Після лікування } & Lim & $5,4-6,6$ & $83,1-109,4$ & $34,8-45,4$ \\
\hline & & $\mathrm{M} \pm \mathrm{m}$ & $6,0 \pm 0,12^{\prime \prime \prime}$ & $95,9 \pm 2,70^{\prime \prime *}$ & $39,6 \pm 1,24$ \\
\hline \multirow{4}{*}{ Дослідна 2} & \multirow{2}{*}{ До лікування } & Lim & $5,9-7,5$ & $96,5-116,3$ & $38,2-47,3$ \\
\hline & & $\mathrm{M} \pm \mathrm{m}$ & $6,7 \pm 0,15^{\circ 00}$ & $107,9 \pm 2,06^{\circ 0}$ & $43,0 \pm 0,95^{\circ}$ \\
\hline & \multirow{2}{*}{ Після лікування } & Lim & $5,1-6,5$ & $81,3-108,2$ & $31,2-43,5$ \\
\hline & & $\mathrm{M} \pm \mathrm{m}$ & $5,8 \pm 0,15^{\prime \prime \prime *}$ & $93,8 \pm 2,58 \cdots * * *$ & $37,9 \pm 1,17^{\prime \prime}$ \\
\hline
\end{tabular}

Таблиця 2

Кількість лейкоцитів у відлучених поросят до і після лікування гастроентериту (n = 10)

\begin{tabular}{|c|c|c|c|}
\hline \multirow{2}{*}{ Група } & \multirow{2}{*}{ Період дослідження } & \multirow{2}{*}{ Біометричний показник } & Показник \\
\hline & & & Лейкоцити, Г/л \\
\hline \multirow{2}{*}{\multicolumn{2}{|c|}{ Клінічно здорові }} & Lim & $9,7-13,9$ \\
\hline & & $\mathrm{M} \pm \mathrm{m}$ & $12,3 \pm 0,39$ \\
\hline \multirow{5}{*}{ Контрольна } & \multirow{2}{*}{ До лікування } & Lim & $13,7-19,5$ \\
\hline & & $\mathrm{M} \pm \mathrm{m}$ & $16,6 \pm 0,69^{\circ \circ \circ}$ \\
\hline & \multirow{2}{*}{ Після лікування } & Lim & $12,8-16,2$ \\
\hline & & $\mathrm{M} \pm \mathrm{m}$ & $13,9 \pm 0,36^{\prime \prime 00}$ \\
\hline & \multirow{2}{*}{ До лікування } & Lim & $13,5-20,1$ \\
\hline \multirow{3}{*}{ Дослідна 1} & & $\mathrm{M} \pm \mathrm{m}$ & $17,1 \pm 0,85^{\circ \circ \circ}$ \\
\hline & \multirow{2}{*}{ Після лікування } & Lim & $10,4-14,4$ \\
\hline & & $\mathrm{M} \pm \mathrm{m}$ & $12,5 \pm 0,41^{\prime \prime \prime *}$ \\
\hline \multirow{4}{*}{ Дослідна 2} & \multirow{2}{*}{ До лікування } & Lim & $13,2-19,9$ \\
\hline & & $\mathrm{M} \pm \mathrm{m}$ & $16,9 \pm 0,92^{\circ \circ \circ}$ \\
\hline & \multirow{2}{*}{ Після лікування } & Lim & $10,1-13,9$ \\
\hline & & $\mathrm{M} \pm \mathrm{m}$ & $12,6 \pm 0,36^{\prime \prime \prime *}$ \\
\hline $\begin{array}{c}\kappa u:^{\prime}-\mathrm{P} \\
\circ-\mathrm{P}< \\
*-\mathrm{P} \\
\wedge-\mathrm{P}\end{array}$ & $\begin{array}{l}{ }^{\prime}-\mathrm{P}<0,01 ; " '-\mathrm{P}<0 \\
-\mathrm{P}<0,01 ;{ }^{\circ \circ}-\mathrm{P}< \\
*-\mathrm{P}<0,01 ; * * *-\mathrm{P} \\
\wedge-\mathrm{P}<0,01 ; \wedge \wedge \wedge-\mathrm{P}\end{array}$ & $\begin{array}{l}\text { оівняно з поросятами до } \\
\text { орівняно } 3 \text { клінічно здо } \\
\text { порівняно } 3 \text { контрольно } \\
\text { Д1 порівняно } 3 \text { Д2 }\end{array}$ & $\begin{array}{l}\text { ми, } \\
\text { нт після лікування, }\end{array}$ \\
\hline
\end{tabular}


Проте, в поросят дослідних груп кількість лейкоцитів була меншою (Р < 0,05) на 10,1 і 9,4\%, порівняно із величинами контрольної групи, і не відрізнялася від значень клінічно здорових тварин. Важливо зазначити, що застосування пробіотика та фітобіотика позитивно вплинуло на лейкоцитопоез поросят, на що вказує нормалізація кількості лейкоцитів у крові дослідних тварин.

Оцінку ефективності обраних методів для лікування поросят, хворих на гастроентерит, визначали 3 використанням достатньої кількості тварин на базі ПАП «Агропродсервіс». Хворих поросят 30-добового віку розділяли на контрольну $(\mathrm{K}, \mathrm{n}=64)$ і дві дослідні (Д1, n =67 і Д2, n = 61) групи та лікували згідно 3 вищезазначеними схемами.

Період одужання поросят оцінювали 3 моменту повного зникнення у них симптомів гастроентериту (нормалізація температури тіла, частоти дихання, пульсу, припинення діареї, зникнення явищ пригнічення, зневоднення та інтоксикації організму тощо).

Таблиця 3

Терапевтична ефективність застосованих препаратів для лікування поросят, хворих на гастроентерит

\begin{tabular}{lccccc}
\hline \multirow{2}{*}{ Група } & \multicolumn{2}{c}{ Одужало } & \multicolumn{2}{c}{ Загинуло } & \multirow{2}{*}{ Дні лікування } \\
\cline { 2 - 5 } & тварин & $\%$ & тварин & $\%$ & $7-9$ \\
Контрольна група $(\mathrm{n}=64)$ & 51 & 79,7 & 13 & 20,3 & $5-7$ \\
Дослідна 1 $(\mathrm{n}=67)$ & 61 & 91,0 & 5 & 7,5 & $3-5$ \\
Дослідна 2 $(\mathrm{n}=61)$ & 59 & 96,7 & 2 & 3,3 & 3 \\
\hline
\end{tabular}

Лікування поросят, що включало застосування $10 \%$ розчину енрофлоксацину гідрохлориду (контрольна група), сприяло поліпшенню клінічного стану хворих тварин на 7-9-ту добу, тоді як у поросят, яким додатково застосовували пробіотик ТОЙОЦЕРІН $10^{9}$ (перша дослідна група) - на 5-7-му та фітобіотик ЕКСТРАКТтм 6930 (друга дослідна група) - на 3-5-ту добу (табл. 3).

Застосування пробіотика ТОЙОЦЕРІН $10^{9}$ та фітобіотика ЕКСТРАКТтм 6930 у поєднанні з антибіотиком сприяло скороченню терміну клінічного одужання тварин на 2 і 4 доби та підвищило їх збереженість на 12,8 i $17,0 \%$, порівняно з контрольною групою (табл. 3).

\section{Висновки}

Встановлено позитивний вплив пробіотика та фітобіотика на стан еритро- і лейкоцитопоезу, на що вказують нормалізація кількості гемоглобіну, еритроцитів, гематокритної величини, лейкоцитів, вмісту гемоглобіну і гематокритної величини у крові до рівня показників клінічно здорових тварин.

Застосування пробіотика ТОЙОЦЕРІН $10^{9}$ і фітобіотика ЕКСТРАКТТ 6930 у поєднанні з антибіотиком сприяло зникненню в поросят симптомів гастроентериту та скороченню терміну клінічного одужання тварин на 2 і 4 доби, порівняно до контрольної групи.

Крім того, застосування пробіотика ТОЙОЦЕРІН $10^{9}$ та фітобіотика ЕКСТРАКТтм 6930 у поєднанні 3 антибіотиком підвищило збереженість поросят дослідних груп на 12,8 і 17,0\%, порівняно з контрольною групою.

\section{References}

Holman, D.B., \& Chénierab, M.R. (2015). Antimicrobial use in swine production and its effect on the swine gut microbiota and antimicrobial resistance. Canadian Journal of Microbiology. 61(11), 785-798. doi: 10.1139/cjm-2015-0239.

Chowdhury, R., Haque, M.N., Islam, K.M.S., \& Khaleduzzaman, A.B.M. (2009). A review on antibiotics in an animal feed. Bangladesh Journal of Animal Science. 38(1\&2), 22-32. https:/www.banglajol.info/index.php/BJAS/article/vie w/9909/7359.

Cromwell, G.L. (2002). Why and how antibiotics are used in swine production. Animal Biotechnology. 13(1), 727. https://www.ncbi.nlm.nih.gov/pubmed/12212945.

Silva, M.L.F., Lima, J.A.F., \& Cantarelli, V.S. (2010). Probiotics and antibiotics as additives for sows and piglets during nursery phase. Revista Brasileira de Zootecnia. 39(11), 2453-2459. doi: 10.1590/S151635982010001100019.

Živković, B., Migdał W., \& Radović, Č. (2011). Probiotics in nutrition of sows and piglets. Biotechnology in Animal Husbandry. 27(3), 547-559. doi: 10.2298/BAH1103547Z.

Kiczorowska, B., Samolinska, W., \& Al-Yasiry, A.R.M. (2017). The natural feed additives as immunostimulants in monogastric animal nutrition - a review. Annals of Animal Science. 17(3), 605-625. doi: 10.1515/aoas-2016-0076.

Jacela, J.Y., DeRouchey, J.M., \& Tokach, M.D. (2010). Feed additives for swine: Fact sheets - prebiotics and probiotics, and phytogenics. Kansas Agricultural Experiment Station Research Reports. 18(3), 132-136. doi: 10.4148/2378-5977.7067.

Kommera, S.K., Mateo, R.D., Neher, F.J., \& Kim, S.W. (2006). Phytobiotics and Organic Acids As Potential Alternatives to the Use of Antibiotics in Nursery Pig Diets. Asian-Australasian Journal of Animal Sciences. 19(12), 1784-1789. doi: 10.5713/ajas.2006.1784.

Vlizlo, V.V., Fedorchuk, R.S., \& Ratych, I.B. (2012). Laboratorni metody doslidzhen' u biologii', tvarynnyctvi ta veterynarnij medycyni: dovidnyk. L'viv: SPOLOM (in Ukrainian).

Official Journal of the European Union L276/33 (2010). Directive 2010/63/eu of the european parliament and of the council of 22 September 2010 on the protection of animals used for scientific purposes. 86/609/EC. 20.10.2010. http://eur-lex.europa.eu/LexUriServ/ LexUriServ.do?uri=OJ:L:2010:276:0033:0079:en:PDF. 